\title{
ASSESS THE PREVALENCE AND COMPARE THE RISK FACTORS OF TYPE 2 DIABETES MELLITUS AMONG ALCOHOLIC AND NONALCOHOLIC MALES RESIDING AT MEDAVAKKAM, CHENNAI \\ *Mrs. Thivya
}

\section{INTRODUCTION:}

The prevalence of type 2 diabetes mellitus is rapidly increasing all over the globe at an alarming rate. Besides several risk factors there is growing consensus that alcohol consumption has an influencing factor for developing Type 2 Diabetes mellitus. The biological mechanism is uncertain but there are several factors including increase in insulin sensitivity after alcohol consumption, changes in the level of alcohol metabolites which increase the high density Lipoprotein cholesterol concentrations. Therefore drinking heavy alcohol in people may cause blood glucose to rise.

\section{STATEMENT OF PROBLEM:}

Assess the prevalence and compare the risk factors of type 2 diabetes mellitus among alcoholic and nonalcoholic males residing at Medavakkam., Chennai.

\section{OBJECTIVES OF THE STUDY:}

- To assess the prevalence of Type 2 Diabetes Mellitus among adult males

- To compare the risk factors of Type 2 Diabetes Mellitus among alcoholic and non alcoholic males.

- $\quad$ To associate the selected demographic variables with the risk factors of type 2 Diabetes Mellitus among alcoholics and non alcoholic males.

\section{RESEARCH METHODOLOGY:}

* Research Design: Non- Experimental exploratory design

* Population: Adult males having the habit of Alcohol consumption with the history of Type 2 Diabetes mellitus residing at Medavakkam rural area.

- Sample size: 100 males ( 50 alcoholic and 50 non alcoholic males) with known Type 2 Diabetes mellitus

* Sampling Technique: Simple Random Sampling using lottery method

\section{INSTRUMENT:}

Part I- It consists of demographic data which includes age, type of family, marietal status, religion, educational status, Occupation, Family income, Habit of Alcohol consumption.

Part II- it consists of multiple choice questions to assess the risk factors of Type 2 Diabetes mellitus like physical parameters, Hereditary, Dietary pattern, lifestyle, stress.

\section{RESULTS AND DISCUSSION:}

$>\quad$ The present study reveals that among the male population $13.6 \%$ of the males are having diabetes and the percentage proportion of the diabetes is $95 \%$ with the confidence interval of 11.92-14.88.

$>\quad$ Regarding the comparison of risk factors like family history of Hypertension and Obesity, habit of taking fast food, using palm oil for

*Asst. Professor, Kasturba Gandhi Nursing College, SBV, Puducherry. 
cooking, habit of fasting, not doing exercise regularly, stress and recurrent infection are found to be significant among alcoholic and non alcoholic males.

$>\quad$ The findings reveals that on association of risk factors with the demographic variables of age was found to be significant with family history diabetes and Body mass Index and there is a significance among history of Hypertension and doing exercise and also stress factor is associated with Marital status and Educational status

Table 1: Distribution of Prevalence of Type 2 Diabetes Mellitus among males.

\begin{tabular}{|l|l|}
\hline Total population of Males & 2029 \\
\hline $\begin{array}{l}\text { Males with Type 2 } \\
\text { diabetes Mellitus }\end{array}$ & 271 \\
\hline Percentage Proportion & $95 \%$ \\
\hline Confidence Interval & $\begin{array}{l}13.36 \%(11.92- \\
14.88)\end{array}$ \\
\hline
\end{tabular}

\section{CONCLUSION:}

The study findings reveal that alcoholism is one of the major factors for causing Type 2 Diabetes mellitus. Among the alcoholic and nonalcoholic males level of stress and history of hypertension are at greater significance. Hence alcoholic and nonalcoholic males must be aware of their risk factors associated with Type 2 Diabetes Mellitus in order to promote their health by being on regular treatment and periodical follow up.

\section{REFERENCES:}

- Black M.Joyce (2005), Medical Surgical Nursing, Philadelphia; J.B , Lippincott publishers.

- Claudia and Smith (2000), Community Health Nursing Theory and practice, Philadelphia; W.B. Saunders publishers.

- Marica Stanhope Lancaster (1992), Community Health Nursing London, Mosby Publishers.

- Watia Kapoor (2004) Diabetes Education Course Diabetes Education for Health care professionals, Interaction Diabetes Federation, Chennai.

- Ajani UA et al (2000), Alcohol consumption and risk of Type 2 Diabetes Mellitus, archieves of internal Medicine Volume 160: 1025- 1030

- WHO technical report series 646, 2008 WHO expert committee on Diabetes mellitus, Second Report. 